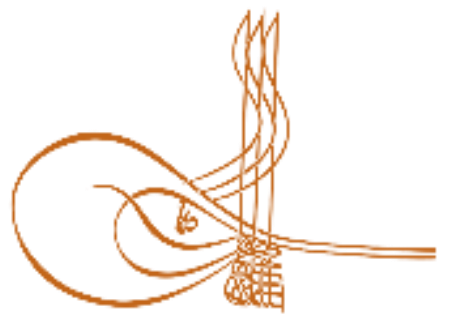

www.turkishstudies.net/turkishstudies
Turkish Studies

eISSN: $1308-2140$

Research Article / Araştırma Makalesi

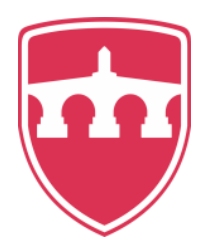

INTERNATIONAL

BALKAN

UNIVERSITY

Sponsored by IBU

\title{
Ortaokul 6.Sınıf Türkçe Ders Kitaplarındaki Metin-Resim İlişkisinin Metni Anlamlandırmaya Etkisinin Öğretmen Görüşleri Açısından İncelenmesi
}

\author{
An Investigation of the Effect of Text-Picture Relationship in the Secondary School 6th Grade \\ Turkish Language Tectbooks on the Comprehension of the Text in Terms of Teacher's Views
}

\author{
Mehmet Fatih Özcan*
}

\begin{abstract}
Textbooks, which are at the top of the tools most used by teachers and students in the education and training process, are also of great importance in achieving the objectives of the teaching. The textbooks, which are easy to access, should be prepared in a way that fits student level in terms of form and content and supports student development while being prepared. Textbooks, which are not regarded as mere sources of information according to the contemporary understanding of education, are designed in a way that both informs students and gives them aesthetic pleasure. The preparation of these books in consideration of the qualifications required of the tools used in education helps to achieve the educational objectives. In this study, it is aimed to reveal the relationship between the pictures and the texts in the 6th grade Turkish textbook published by the Ministry of National Education in 2018-2019 academic year and to examine them in terms of teachers' opinions. In this research, correlational survey model was used. In the research, a 5-point Likert-type scale, which developed by Baş and Yildız (2014) and whose internal consistency coefficient (Cronbach alpha) was .92 and a Personal Information Protocol developed by the researcher to collect demographic information were used. The population of the study is the Turkish teachers working in Ağrı, the sample of the study consisted of Turkish teachers who had professional experience, who worked in Patnos district of Ağr province and who attended 6th grade Turkish course. A total of 43 teachers, 28 males and 15 females, participated in the study. According to the findings, there is a significant difference of opinion among Turkish teachers about the association of pictures with daily life, and it is found that Turkish teachers' opinions about text-picture relationship do not show a significant difference depending on gender, age, education status and service period variables.
\end{abstract}

Structured Abstract: The study "Examination of the Effect of Text-İmage Relation on Comprehension of Text in Turkish Language Textbooks" was dealt to evaluate the effect of text-image relationship on comprehension of text in secondary school Turkish language textbooks in terms of teachers' views.

1. Are the images appropriate to the level of development of the students?

\footnotetext{
* Dr. Öğr. Üyesi, Ağrı İbrahim Çeçen Üniversitesi, Eğitim Fakültesi, Türkçe ve Sosyal Bilimler Eğitimi Bölümü Asst. Prof. Dr., Ağrı İbrahim Çeçen Üniversity, Faculty of Education, Department of Social Sciences and Turkish Language Teaching

ORCID 0000-0002-0721-9422

mefo3@hotmail.com

Cite as/ Atıf: Özcan, M.F. (2020). Ortaokul 6. sınıf Türkçe ders kitaplarındaki metin-resim ilişkisinin metni anlamlandırmaya etkisinin öğretmen görüşleri açısından incelenmesi, Turkish Studies, 15(1), 519-534. https://dx.doi.org/10.29228/TurkishStudies.39719

Received/Geliş: 12 November/Kasım 2019

Accepted/Kabul: 25 February/Şubat 2020

Copyright $\odot$ MDE, Turkey

Checked by plagiarism software

Published/Yayın: 29 February/Şubat 2020

CC BY-NC 4.0
} 
2. Do the images have aesthetic value that could be of interest to children?

3. Are images effective in developing students' imagination?

4. Do the images raise curiosity about reading the text?

5. Are the images suitable for the content of the text?

6. Do the images support messages that are intended to be highlighted in the text?

7. Are the text and the image associated with it on the same page?

8. Do the images vary according to the type of text?

Sub-problems consisting of such questions have emerged. With this study, it was aimed to determine the relationship between the text and the meaning of the text by correctly reading and analyzing the images in the textbooks in the schools. The reason for this is to see how the secondary school students can comprehend the text-image relationship and to ensure that the deficiencies are eliminated. It is important that this study raises awareness for teachers and students and contributes to the literature.

In the theoretical part of the study, a wide literature review is made and the studies on the features of the course book in Turkish language course program, how the relationship between textbook and visuality should be, the effect of aesthetic elements on student development and the aesthetical elements that should be included in the textbooks were examined. In this study, 6th grade Eksen Publications Turkish Language textbook was used. This book was accepted as a textbook for 5 (five) years starting from the 2018-2019 academic year by the decision of the Board of Education and Training Board of the Ministry of National Education dated 28 May 2018 and numbered 78.

In this research, relational scanning model was used to investigate the effect of text-image relationship on textual comprehension in 6th grade textbooks. The Correlational Survey model is the surveying arrangements made on the whole population or a group or sample to be taken in order to reach a general judgment about the population in a population consisting of many elements (Karasar, 1994). Turkish language teachers working in Ağrı were chosen as the population of the study. The sample of the study was randomly selected from Turkish language teachers working in Patnos district of Ağrı, who attended the 6th grade Turkish course, and it was grounded on volunteering. It is seen that teachers participating in the study were mostly in the 25-31 age range; $97.7 \%$ of them are bachelor and $2.3 \%$ of them have master's degree and there are no teachers with doctorate degree. In addition, $37.2 \%$ of the study group consisted of teachers with 1-3 years professional seniority, $37.2 \%$ was with 3-6 years, $18.6 \%$ was with 7-10 years, $4.7 \%$ was with 10-15 years and $2,3 \%$ was with 15 years or more professional seniority. It is seen that Turkish language teachers are mostly between 1-3 and 3-6 years of professional seniority.

5-point Likert-type scale ("Strongly Agree, Agree, Neutral, Disagree, Strongly Disagree”; grading score is 5-4-3-2-1) developed by Baş and Yıldiz (2014) as a data collection tool and Personal Information Protocol developed by the researcher was used to collect the data in the research.

In the conclusion part of the research, it was found that;

1- The fact that the percentages of the agree-disagree answers given to the item "Images are related to daily life" is close reveals that the book-image are not coherent from the point of view of the teacher.

2- The fact that the percentages of answers given to the item "No logic errors are made in the images", as in the previous item will create a problem of logical comprehension for the students at secondary level.

3- When the answers to the items "The colors that are desirableness were used in the image" and "The dull and pale colors were used in the paintings were used in the images" were analyzed, it was determined that the ratio of the answer "Neutral" was higher. Colors can help brain development, creativity, efficiency and learning; and they are important in terms of drawing attention.

4- The other results of the research show that images improve students' prediction, estimation and estimation skills, attention is paid to the relationship between text and background, the images overlap with the story elements in the text, the images support the messages given in the text, the images arouse curiosity, they are placed on the page appropriately, that the texts support the headings, referring to the concepts contained in 
the text, that the image-text relationship is in accordance with the constructivist approach, that the text and the image move in harmony with each other, different visual elements are included in the image. Kılıç and Seven (2007) stated that in addition to photographs and illustrations, different visual elements are included in the textbooks.

5- It is seen that Turkish language teachers are mostly between the ages of 25-31 and with 1-3 and 3-6 years of professional seniority. This situation is advantageous both for the students in terms of age range and disadvantageous in terms of service period and experience.

6- Considering the opinions of Turkish language teachers about the relationship between text and image, the views of Turkish language teachers do not differ according to gender, age, educational background and terms of office.

In the last part of the research, some recommendations were made for the researchers who will study on the subject. Some of these recommendations are as following:

1- The images to be covered in the textbooks should be adequately related to daily life.

2- Images have a very important place to comprehend the text. Therefore, logic errors in the images have a negative effect on the comprehension of the text. Images prepared by visual designers should be in logical integrity and attention should be paid to this.

3- Colors, which are important stimulants for the students, should be included in the textbooks in accordance with the cognitive and affective levels of the students. Teachers should also consider the colors in the images.

4- Texts should be enriched with visual elements.

Keywords: Turkish Language Teaching, textbook, picture-text relationship, aesthetics

Öz: Eğitim-öğretim sürecinde öğretmen ve öğrencilerin en çok kullandıkları araçların başında gelen ders kitapları, öğretimin amaçlarına ulaşmasında da büyük öneme sahiptir. Kolay erişilen bir kılavuz özelliği taşıyan ders kitapları, hazırlanırken biçim ve içerik açısından öğrenci seviyesine uygun ve öğrenci gelişimini destekler şekilde ele alınır. Çağdaş eğitim anlayışına göre salt bilgi kaynağı olarak görülmeyen ders kitapları, hem öğrenciye bilgi verecek hem de estetik zevk kazandıracak bir biçimde tasarlanmaktadır. Söz konusu kitapların, eğitimde kullanılan araç-gereçlerin sahip olması gereken nitelikler göz önünde bulundurularak hazırlanması eğitsel amaçların gerçekleşmesine yardımcı olmaktadır. Bu araştırmada 2018-2019 eğitim-öğretim yılında Milli Eğitim Bakanlığı tarafından yayımlanan 6. sınıf Türkçe ders kitabında yer alan resimlerin, metinlerle olan ilişskisinin ortaya konulması ve öğretmen görüşleri açısından incelenmesi amaçlanmıştır Bu araştırmada ilişkisel tarama modeli kullanılmıştır. Araştırmada veri toplama aracı olarak Baş ve Yıldız (2014) tarafından geliştirilen ve iç tutarlık kat sayısı (Cronbach alpha) .92 olarak bulunan, 5'li Likert tipi ölçek, demografik bilgileri toplamak için ise araştırmacı tarafından geliştirilen Kişisel Bilgi Formu kullanılmıştır. Araştırmanın evrenini Ağrı'da görev yapan Türkçe öğretmenleri; araştırmanın örneklemini ise Ağrı ili Patnos ilçesinde görev yapan, 6.sınıf düzeyinde Türkçe dersine giren Türkçe öğretmenleri oluşturmuştur. Araştırmaya 28'i erkek, 15'i ise kadın olmak üzere toplam 43 öğretmen katılmıştır. Elde edilen bulgular doğrultusunda resimlerin günlük hayatla ilişkilendirilmesi konusunda, Türkçe öğretmenleri arasında ciddi bir görüş farkı olduğu; ayrıca Türkçe öğretmenlerinin metin-resim ilişkisine yönelik görüşleri cinsiyet, yaş, öğrenim durumu ve hizmet süresi değişkenlerine bağlı olarak anlamlı bir farklılık göstermediği tespit edilmiştir.

Anahtar Kelimeler: Türkçe Öğretimi, ders kitabı, resim-metin ilişkisi,

\section{Giriş}

Türkçe öğretiminde temel unsurlardan birisi ders kitabıdır. Ders kitabı, öğrencilerin temel olarak derslerde kullanacağı, dilsel bildirimleri alacağı, temel dil becerilerini edineceği ve geliştireceği temel materyallerdendir. 
Türkçe Dersi Öğretim Programında (2018, s.8) öğrencilerin basılı materyallerden bilgiye ulaşma, bilgiyi etkili bir şekilde kullanma ve sentez yapma becerilerini geliştirmek hedeflenmektedir. $\mathrm{Bu}$ doğrultuda Milli Eğitim Bakanlığının Ders Kitapları ve Araçları Yönetmeliği (2012) 9. maddesinde belirtilen ders kitabında olması gereken nitelikler şu şekilde belirtilmiştir:

- Anayasa ve kanunlara aykırı hususları içermez.

- Bilimsel hata içermez.

- Temel insan hak ve özgürlüklerini destekleyen ve her türlü ayrımcılığı reddeden bir yaklaşım sunar.

- Reklam niteliğinde ögeler içermez.

- Eğitim ve öğretim programının amaçladığı kazanımları kapsar.

- Görsel tasarım ve içerik tasarımı, öğrenmeyi destekleyecek nitelikte ve öğrencilerin gelişim özelliklerini dikkate alarak yapılır.

Yukarıdaki maddeler göz önüne alındığında altı temel nitelikten birisi olan "Görsel tasarım ve içerik tasarımı, öğrenmeyi destekleyecek nitelikte ve öğrencilerin gelişim özelliklerini dikkate alarak yapılır." maddesi ders kitaplarındaki görselliğin önemini göstermektedir.

Ders kitaplarındaki görsel tasarımın genel amacı, öğrenciyi kitaba yakınlaştırmak, kitabı ilgi çekici hâle getirmektir. Ders kitaplarındaki resimlemeler, çocuğa bilgi ve davranış kazandırma amacını güder. Resimlemelerdeki görsellik ve estetik unsurlar ne kadar kaliteliyse algılama da o kadar iyi olmaktadır. Çocukların estetik duygularının gelişmesinde ve kitap okuma alışkanlığ 1 edinmelerinde iyi tasarlanmış kitapların rolü büyüktür (Uzuner, Aktaş ve Albayrak, 2010, s.723). Bu görsel öğelere "illüstrasyon" adı verilmektedir. İllüstrasyon TDK'de (2019) "resimleme" olarak tanımlanmaktadır. İllüstrasyonlar, kavramlar oluşturabildiği gibi, metinden bağımsız olarak tek başına anlam bütünlüğü de sağlayabilir (Mardi, 2006, s.4). Becer'e (1996, s.140) göre illüstrasyonlar, okuyucuya sadece bilgi verme amacı olmadan, okuyucunun dikkatini çeken, görsel kültür ve beğeni düzeyini yükselten, metinde sözü edilen olguyu görselleştiren çalışmalardır. Estetik bakışın çocukta özgün düşünme, üretme ve deneme kapasitelerini geliştirebilme; çevreye estetik bakış açısı kazandırma; hayal gücünü geliştirerek bireyin estetiğin (güzelliğin) insan yaşamındaki yeri ve önemini kavramasını, estetik duyarlılığın gelişmesi, çok yönlü ve açık fikirli düşünebilme, etkileşime ve iletişime açık olma, kültürel değerlerini tanıma gibi davranışlar kazandırır. İşcan, vd. (2007, s.9) estetiğin Türkçe eğitimine yönelik amaçları ve öğrencilere kazandıracağı davranışları şu şekilde sıralamıştır:

- Özgün düşünme, üretme ve deneme kapasitelerini geliştirebilme,

- Çevresini güzelleştirmesini sağlayacak estetik kişilik kazandırabilme,

- Sanat güzelliğini ve sanatçıyı takdir etmesini sağlayabilme,

- Hayal gücünü geliştirebilme, maddelerinden hareketle birey; estetiğin (güzelliğin) insan yaşamındaki yerini ve önemini kavrar, edindiği deneyimlerle, yaratıcıllğa ve üretkenliğe kolayca geçebilecek, yeniliklere açık kişiliğini topluma yansıtır. Bu da bireyin sanatsal olguları değerlendirip, eleştirmesine, tüm çevresinde güzeli ve iyiyi aramasına yardımcı olur. Birey sanatsal bakış ile kültürel değerlerin farkına varan, açık fikirli, etkileşime ve iletişime açık biri haline gelir.

Amaç metinden hareketle resimleme yapma ve resimlemelerle metin hakkında bilgi vermektir. Resim-metin ilişkisinin yanında yukarıda bahsedilen maddeler 1şığında çocuğun ilgisini çekecek, estetik değerlere sahip olması gerekmektedir. Resim+metin= estetik gibi bir formül oluşturulabilir. Buradan resim-metin ilişkisinin estetik değerleri vermesi oluşturulmak istenen yararlar için olmazsa olmazlardandır Gönen, Katrancı, Uygun \& Uçuş'a (2011, s.264) ve Arı'ya 
(2008) göre çocuk kitaplarında yer alan resimlerin açık, anlaşılır, konuya uygun olmasına ve sanatsal değerler taşımasına özen gösterilmelidir.

Eğitim faaliyetin olmazsa olmazı ders kitaplarıdır. Ders kitapları hem öğrenci için hem de öğretmen için önemli birer kaynaktır. Ders kitabı ulaşılmak istenen eğitim amaçlarının aracıdır. Bu amacın gerçekleşmesi için de içerik ve tasarım olarak nitelikli kitapların basılması gerekmektedir. Demirel' e (2005. S.39) göre kaliteli eğitim, büyük oranda kaliteli ders kitaplarıyla gerçekleşecektir. Planlı eğitim uygulamalarında kullanılan ders kitapları; açıklayıcı, yönlendirici, tamamlayıcı resim, grafik, şekil gibi öğretim materyallerine yer vererek öğrenme-öğretme sürecini daha canl1, ilgi çekici ve aktif hâle getirebilir (Küçükahmet 2001: 20). Etkili bir ders kitab1 "görsel zenginlik içermeli, albenisi olmalı, renkli resim ve fotoğraflarla desteklenmelidir." (Şahin-Yıldırım 1999).

Ders kitapları resmedilirken diğer kitaplardan farklılık göstermelidir. Ders kitaplarında yer alan resimlemeler "dekorasyonel, temsilsel ve dönüşümsel resimler" olarak ele alınması gerekmektedir. Carney ve Levin'e (2002) göre dekorasyonel resimlemelerin metinden öğrenmede neredeyse hiç yararlı etki göstermezken; temsilsel resimlerin orta, dönüşümsel resimlerin ise çok önemli yarar sağladığı görüşündedir. Dekorasyonal resimler metin içeriğiyle çok fazla bağlantılı olmadan sadece sayfayı dekore ederler (Kayabekir, 2010, s.51). Resimle-metin arasında bir ilişki yoksa sadece sayfayı dekore etme amacı güdülmüşse; okuyucunun metinden anladığı ile resimden gördüğü arasında bir ilişki kurulamıyorsa dekorasyonal resimleme yapılımıştır. Temsilsel resimler metin içeriğinin ya bir kısmını ya da bütünü yansıtır ve en çok kullanılan resimleme tipidir. Dönüşümsel resimler ise okuyucunun metin bilgilerini hatırlamalarını geliştirmek için tasarlanan sistematik anımsatıcı (hafiza geliştiren) elemanları içerir (Kayabekir, 2010, s.51). Oğuzkan'a (2001, s.365) göre ise ders kitaplarında kullanılan resimlemelerin, metni süsleyici, metni açıklayıcı, yorumlayıcı ve metni tamamlayıcı işlevleri vardır. Metni açıklayıcı ve metni tamamlayıcı resimler aynı temsilsel ve dönüşümsel resimler gibi hazırlanacak ders kitabı için ve çocuğun anlaması için önem arz etmektedir. Süsleyici resimlerin ise konunun açıklanmasından çok duygu ve hayal gücünün gelişmesinde etkili olacağı için öncelikle halk hikayelerinde, şiirlerde ve kütüphane kitaplarında yer almas1 daha uygundur (Soydan, 2014, s.89).

Ceyhan ve Yiğit'e (2005, s.102-103) göre öğretim amacı taşıyan ders kitaplarında kullanılacak olan resimlerde dikkat edilmesi gereken ilkeler;

1. Sadelik: ders kitaplarında kullanılan resimler basit ve sade bir şekilde olmalıdır. 2. Denge: Her kısımda kullanılacak olan resimlerin oranının, konuların önemi oranında kullanılması gerekir. 3. Açıklık: Resimler, vermek istediği mesajı açık bir şekilde yansıtmalıdır. 4. Hareket: Resmin ögeleri, tekdüze ve eşit şekilde dağılmamalıdır. Bu durum, resimlere durgun bir özellik katar. Hareketli resimlerde, göz hareketleri de belirgin olan noktalara yönelir ve bakışlar o bölgede yoğunlaşır. 5 . Süreklilik: Göz hareketleri, düşüncede herhangi bir kesiklik olmadan devam edebilmelidir şeklinde belirtilmiştir.

Çocuk okuduğunun karşı1lı̆ını resimlerde görmeyi bekler. Resimlemelerin metnin içeriği ile çelişmemesi, olumsuz anlamlandırmalara yönlendirmemesi gerekir. Özellikle hikâyenin kötü, çirkin ya da karmaşık karakterize edilmiş kahramanı çocuğun kitaba olan ilgisini zayıflatabilir. Resimsel anlatımlar, metinde anlatılanı ortaya koymanın ötesinde, metnin planı ya da ana düşüncesiyle örtüşen ama bunun yanında yeni ve zengin ayrıntılara da sahip yeni bir konumdadır (Kara, 2012, s.229-230). Ders kitaplarındaki başarılı bir görselin görevi, metnin içeriğini görselleştirmesidir. Görselliğin ilk hedefi bilgilendirmek olmalıdır. En önemlisi resimler çocuklarda yeni yaşantılar, yeni bilgiler, yeni değerlendirmeler verebilmelidir (Uzuner, Aktaş \& Albayrak, 2010, s.723).

Resim ve metin ilişkisi, ders kitaplarında bir bütünlük içerisinde düşünülerek verilmelidir. Metin ve resim birbirinden kopuk olmamalıdır. Metin ile resmin bütünleşmesi sağlanarak, buradan ortaya çıkacak görsel zenginlik çocukların dünyalarına sunulmalıdır. Eğer resimler, ait oldukları 
metinden koparsa çocukların ilgisi dağılacak ve resmin görsel anlamdaki etkinliği kaybolmuş olacaktır (Kılıç, 2006, s.24-29).

Resimler de metinler gibi kompozisyon meydana getirirler. Resim-metin ilişkisi üç farklı şekilde olabilir: Resim ve metin aynı sayfada ya da yan yanadır. Çocuk metni okur ve arada resimlere bakar. Böylece metinde anlatılanla, resimde görülenler birbirini destekleyip tamamlar. Resim önce, metin sonra verilir. Bu tasarımda çocuk önce metnin gidişatını tahmin eder. Bu tür tasarımlar, çocukların tahmin etme, kestirme, yordama gibi becerilerini kullanabilmesini hedeflemektedir. Metin önce, resim sonra verilir. Öğrenci önce metni okur; daha sonra okuduğu kurguyu resim kanalı ile pekiştirir (Baş ve Yıldı, 2014, s.139-151).

Karatay ve Pektaş (2012, s.187) resim-metin ilişkisinin birbirini tamamlar nitelikte düzenlenmesi gerektiğini, metin ve resmin iç içe olduğu zamanlarda ise zıt renklerin kullanılarak okuma güçlüğünün ortadan kaldırılmasını, aksi takdirde okuma eyleminin anlama odaklanmaktan çok resmin içindeki metni seçme çabasına dönüşebileceğini belirtmektedir. Bu açıklamaya göre görselle metnin içeriğinin uyumlu olmasının yanında metin-resim renk uyumu ve sayfa düzeninin de uygun olması gerektiği anlaşılmaktadır.

Yukarıdaki açıklamalardan da anlaşılacağı üzere resim-metin ilişkisi bağlamında metnin içeriği ve biçimi için resimlemeler önem arz etmektedir. Alanyazına bakıldığında resimlerin öğrencilerde; estetik zevk, hayal gücü ve yaratıcı düşünme becerilerini geliştirmesinin beklendiği ve buna göre ders kitaplarının hazırlanmasının gerekliliği belirtilmiştir.

\section{Araştırmanın Amacı}

Araştırmanın amacı, ortaokul Türkçe ders kitaplarındaki metin-resim ilişkisinin metni anlamlandırmaya olan etkisini öğretmen görüşleri açısından ortaya koymaktır. Bu amaç çerçevesinde çalışmanın alt problemleri aşağıdaki şekilde belirlenmiştir:

1. Resimler, öğrencilerin gelişim seviyelerine uygun mu?

2. Resimler, çocukların ilgisini çekebilecek estetik değere sahip mi?

3. Resimler, öğrencilerin hayal gücünü geliştirmede etkili mi?

4. Resimler, metni okumaya yönelik merak uyandırmakta mı?

5. Resimler, metnin içeriğine uygun mu?

6. Resimler, metinde vurgulanmak istenen mesajları destekliyor mu?

7. Metin ve onunla ilişkili olan resim aynı sayfada mı yer alıyor?

8. Metnin türüne göre resimler değişkenlik gösterir mi?

Araştırmanın önemi, Türkçe dersinin ana kaynağı olan ders kitaplarında yer alan resimlerin öğrencinin metni anlamasına, anlamlandırmasına ve analiz-çözümleme yöntemlerini kullanarak metni tahmin etmesine ne oranda yardım ettiğini ve eksiklerinin ne olduğunu belirlemektir. $\mathrm{Bu}$ çalışma Ortaokul düzeyindeki öğrencilerin metinlerdeki resimlerle beraber metnin içeriğini somutlaştırarak öğrenmede kalıcılığı sağlaması için eksik görülen yerlerin tespit edilmesi ve düzeltilmesi için tavsiyelerde bulunulması açısından da önemlidir. Bundan dolayı resimler ile metinler arasında güçlü bir ilişki olması gerekmektedir.

\section{Sayıltılar}

1. Araştırmada katılımcıların samimi ve doğru cevaplar verecekleri varsayılmaktadır.

2. Veri toplama aracının tüm yetkileri kapsadığ 1 ve görüşleri ortaya çıkaracak nitelikte olduğu varsayılmaktadır.

\section{Sinırlılıklar}

1. Araştırma Ağrı ili ile sınırlıdır. 
2. Araştırmada 6.sınıf Eksen Yayınları Türkçe ders kitabı kullanılmıştır. Bu kitap, Millî Eğitim Bakanlığı Talim ve Terbiye Kurulu Başkanlığının 28 Mayıs 2018 tarih ve 78 sayılı kararıyla (listenin 253. sırasında) 2018-2019 öğretim yılından itibaren 5 (beş) yıl süreyle ders kitabı olarak kabul edilmiştir.

\section{Yöntem}

\section{Araștırma Modeli}

$\mathrm{Bu}$ araştırmada Ortaokul 6.sınıf ders kitaplarındaki metin-resim ilișkisinin metni anlamlandırmaya etkisinin incelenmesi amaçlanarak ilişkisel tarama modeli kullanılmıștır. İlişkisel Tarama modeli, çok sayıda elemandan oluşan bir evrende, evren hakkında genel bir yargıya varmak amacıyla, evrenin tümü ya da ondan alınacak bir grup, örnek veya örneklem üzerinde yapılan tarama düzenlemeleridir (Karasar, 1994). Geniş bir alanda kullanılma olanağına sahip olan ilişkisel tarama modelinin temel amacı, insanlara sorular sorarak çalışmak istenen konu hakkında neler düşündüklerini ortaya çıkarmaktır. Sorulan bu sorular sonucunda sahip olunan bilgiler doğrultusunda değişkenler arasındaki ilişkilerin belirlenmesini sağlar. Ayrıca varsa ölçeğin veya ölçeklerin alt boyutlarının nasıl değiştiğini ortaya çıkarır (Christensen, Johnson ve Turner, 2015).

Tarama araştırmalarında evrenin tamamına ulaşılmasının çok zor olduğu ön görülerek evrenin bir parçası olan örneklem üzerinde çalışmalar yapılmakta, bu örneklemden elde edilen veriler doğrultusunda tutum ve eğilimlerin nicel veya sayısal olarak betimlenmesi sağlanmaktadır (Creswell, 2013).

\section{Evren-Örneklem}

Araştırmanın evreni olarak Ağrı'da görev yapan Türkçe öğretmenleri seçilmiştir. Araştırmanın örneklemini ise Ağrı ili Patnos ilçesinde görev yapan, 6.sınıf düzeyinde Türkçe dersine giren 89 Türkçe öğretmeninden gönüllülük esasına göre seçilmiştir. Araştırmaya katılan Türkçe öğretmenleri ile ilgili demografik bilgiler aşağıdaki tablolarda sıralanmıştır:

Tablo 1: 6.Sınıf Türkçe Öğretmenlerinin Cinsiyetlerine İlişkin Bilgiler

\begin{tabular}{cccc} 
& Grup & f & $\%$ \\
\cline { 2 - 4 } Cinsiyet & Erkek & 28 & 65,1 \\
\cline { 2 - 4 } & Kadın & 15 & 34,9
\end{tabular}

Araştırmaya 28 'i erkek, 15 'i ise kadın olmak üzere toplam 43 öğretmen katılmıştır. Katılan öğretmenlerin \%65,1'i erkek, \%34,9'u ise kadındır.

Tablo 2: 6.Sınıf Türkçe Öğretmenlerinin Yaşlarına İlişkin Bilgiler

\begin{tabular}{ccccc}
\hline & Grup & $\mathrm{f}$ & $\%$ \\
\cline { 3 - 5 } & $18-24$ & 1 & 2,3 \\
\cline { 3 - 5 } & Yaş & $25-31$ & 30 & 69,8 \\
\cline { 2 - 5 } & $32-38$ & 10 & 23,3 \\
\cline { 2 - 5 } & $39-45$ & 2 & 4,7 \\
\hline
\end{tabular}

Araştırmaya katılan öğretmenlerin \%2,3'ünü 18-24, \%69,8'ini 25-31, \%23,3'ünü 32-38 ve $\% 4,7$ 'sini ise 39-45 yaş grubunda görev yapan öğretmenler oluşturmaktadır. Dolayısıyla Türkçe öğretmenlerinin 25-31 yaş aralığında yoğunlaştı̆̆ görülmektedir.

Tablo 3: 6.Sınıf Türkçe Öğretmenlerinin Öğrenim Durumlarına İlişkin Bilgiler

\begin{tabular}{cccc} 
Öğrenim Durumunuz & Grup & $\mathrm{f}$ & $\%$ \\
\cline { 2 - 4 } & Fakülte & 42 & 97,7 \\
\cline { 2 - 4 }
\end{tabular}


Araştırmaya katılan öğretmenlerin \%97,7'si lisans, \%2,3'ü ise yüksek lisans mezunudur. Araştırmaya doktora derecesine sahip hiçbir öğretmen katılmamıştır.

Tablo 4: 6.Sınıf Türkçe Öğretmenlerinin Hizmet Sürelerine İlişkin Bilgiler

\begin{tabular}{|c|c|c|c|}
\hline \multirow{6}{*}{ Hizmet Süresi } & Grup & $\mathrm{f}$ & $\%$ \\
\hline & $1-3$ & 16 & 37,2 \\
\hline & $3-6$ & 16 & 37,2 \\
\hline & $7-10$ & 8 & 18,6 \\
\hline & $10-15$ & 2 & 4,7 \\
\hline & 15 ve Üstü & 1 & 2,3 \\
\hline
\end{tabular}

Araştırmaya katılan öğretmenlerin \%37,2'sini 1-3, \%37,2'sini 3-6, \%18,6'sını 7-10, $\% 4,7$ 'sini $10-15$ ve $\% 2,3$ 'ünü ise 15 ve üstü hizmet süresinde görev yapan öğretmenler oluşturmaktadır. Dolayısıyla Türkçe öğretmenlerinin 1-3 ve 3-6 yıl aralığında yoğunlaştığı görülmektedir.

\section{Veri Toplama Aracı ve Verilerin Analizi}

Araştırmada veri toplama aracı olarak Baş ve Yıldız (2014) tarafından geliştirilen 5'li Likert tipi ölçek, demografik bilgileri toplamak için ise araştırmacı tarafından geliştirilen Kişisel Bilgi Formu kullanılmıştır.

Ölçeğin yapı geçerliğini belirlemek amacıyla yapılacak olan açımlayıcı faktör analizine uygunluğunu gösteren KMO değerinin .89, Bartlett Küresellik Testi sonucunda elde edilen ki-kare değerinin ise anlamlı olduğu görülmüştür $\left(\chi^{2}(231)=1363,446 ; p<.01\right)$. Ölçeğin iç tutarlık kat sayısı (Cronbach Alpha) .92 olarak hesaplanmıştır.

Araştırmada 5'li Likert tipi dereceleme ölçeği kullanılmıştır. "Kesinlikle Katılıyorum, Katıliyorum, Kararsızım, Katılmıyorum, Kesinlikle Katılmıyorum" şeklindeki dereceleme puanlaması ise 5-4-3-2-1 şeklindedir.

Araştırmada verilerin analizi için SPSS programından faydalanılmış olup, manidarlık düzeyi ise .05 kabul edilmiştir. 


\section{Bulgular}

Tablo 5: Maddelere İlişkin Frekans ve Yüzde Dağılımları

\begin{tabular}{|c|c|c|c|c|c|c|c|c|c|c|}
\hline MADDELER & & 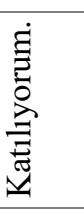 & 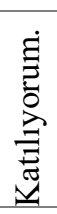 & & 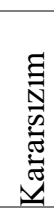 & & 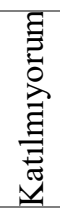 & & & 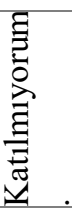 \\
\hline & $\mathrm{f}$ & $\%$ & $\mathrm{f}$ & $\%$ & $\mathrm{f}$ & $\%$ & $\mathrm{f}$ & $\%$ & $f$ & $\%$ \\
\hline $\begin{array}{l}\text { 1. Resimler öğrencilerin sosyal/duygusal } \\
\text { gelişimine uygundur. }\end{array}$ & 7 & 16,3 & 29 & 67,4 & 3 & 7 & 3 & 7 & 1 & 2,3 \\
\hline $\begin{array}{l}\text { 2. Resimler öğrencide sanatsal beğeni } \\
\text { oluşturmaktadır. }\end{array}$ & 6 & 14 & 23 & 53,5 & 8 & 18,6 & 4 & 9,3 & 2 & 4,7 \\
\hline $\begin{array}{l}\text { 3. Resimler metni tahmin etme, kestirme ve } \\
\text { yordama becerilerini geliştirme açısından } \\
\text { yeterlidir. }\end{array}$ & 8 & 18,6 & 21 & 48,8 & 7 & 16,3 & 6 & 14 & 1 & 2,3 \\
\hline $\begin{array}{l}\text { 4. Metin ve resimlerin yerleştirilmesinde zemin- } \\
\text { fon ilişkisine dikkat edilmiştir. }\end{array}$ & 6 & 14 & 17 & 39,5 & 10 & 23,3 & 6 & 14 & 4 & 9,3 \\
\hline $\begin{array}{l}\text { 5. Resimler metindeki hikâye unsurları (olay, } \\
\text { kahraman, zaman ve mekân) ile örtüşmektedir. }\end{array}$ & 6 & 14 & 22 & 51,2 & 12 & 27,9 & 1 & 2,3 & 2 & 4,7 \\
\hline $\begin{array}{l}\text { 6. Resimler metinde verilmek istenen iletileri } \\
\text { desteklemektedir. }\end{array}$ & 3 & 7 & 28 & 65,1 & 10 & 23,3 & 1 & 2,3 & 1 & 2,3 \\
\hline $\begin{array}{l}\text { 7. Resimler öğrencilerin yaratıcı düşünme } \\
\text { becerilerini geliştirmektedir. }\end{array}$ & 4 & 9,3 & 22 & 51,2 & 5 & 11,6 & 8 & 18,6 & 4 & 9,3 \\
\hline $\begin{array}{l}\text { 8. Resimler öğrencide metni okumaya yönelik } \\
\text { merak uyandırmaktadır. }\end{array}$ & 3 & 7 & 25 & 58,1 & 8 & 18,6 & 5 & 11,6 & 2 & 4,7 \\
\hline $\begin{array}{l}\text { 9. Resimler öğrencilerin hayal gücünü } \\
\text { geliştirmeye yöneliktir. }\end{array}$ & 4 & 9,3 & 19 & 44,2 & 11 & 25,6 & 8 & 18,6 & 1 & 2,3 \\
\hline $\begin{array}{l}\text { 10. Resimlerin sayfadaki konumlandırması } \\
\text { uygundur. }\end{array}$ & 5 & 11,6 & 19 & 44,2 & 9 & 20,9 & 6 & 14 & 4 & 9,3 \\
\hline $\begin{array}{l}\text { 11. Resimler metinlerin başlıklarını } \\
\text { desteklemektedir. }\end{array}$ & 5 & 11,6 & 24 & 55,8 & 11 & 25,6 & 2 & 4,7 & 1 & 2,3 \\
\hline $\begin{array}{l}\text { 12. Resimler metinde yer alan kavramlara } \\
\text { gönderme yapmaktadır. }\end{array}$ & 6 & 14 & 26 & 60,5 & 8 & 18,6 & 2 & 4,7 & 1 & 2,3 \\
\hline 13. Resimler günlük hayatla ilişkilidir. & - & - & 14 & 32,6 & 12 & 27,9 & 12 & 27,9 & 5 & 11,6 \\
\hline $\begin{array}{l}\text { 14. Ders kitaplarındaki resim-metin ilişkisi } \\
\text { yapılandırmacı yaklaşıma göredir. }\end{array}$ & 1 & 2,3 & 22 & 51,2 & 9 & 20,9 & 5 & 11,6 & 6 & 14 \\
\hline $\begin{array}{l}\text { 15. Metinler için yeterli sayıda görsel } \\
\text { kullanılmıştır. }\end{array}$ & 3 & 7 & 15 & 34,9 & 8 & 18,6 & 13 & 30,2 & 4 & 9,3 \\
\hline 16. Resimlerde mantık hataları yapılmamıştır. & 2 & 4,7 & 13 & 30,2 & 9 & 20,9 & 13 & 30,2 & 6 & 14 \\
\hline $\begin{array}{l}\text { 17. Metin ve resim birbirinin önüne geçmemekte } \\
\text { ya da birbirinden geri kalmamaktadır. }\end{array}$ & 1 & 2,3 & 17 & 39,5 & 8 & 18,6 & 10 & 23,3 & 7 & 16,3 \\
\hline $\begin{array}{l}\text { 18. Resimlerde albeni oluşturan renkler } \\
\text { kullanılmıştır. }\end{array}$ & 3 & 7 & 12 & 27,9 & 13 & 30,2 & 11 & 25,6 & 4 & 9,3 \\
\hline $\begin{array}{l}\text { 19. Metin için resimlerin yanı sıra karikatür, } \\
\text { fotoğraf, grafik vb. öğelere yer verilmiştir. }\end{array}$ & 4 & 9,3 & 30 & 69,8 & 1 & 2,3 & 4 & 9,3 & 4 & 9,3 \\
\hline $\begin{array}{l}\text { 20. Resimlerde mat ve soluk renkler } \\
\text { kullanılmamiştır. }\end{array}$ & 5 & 11,6 & 11 & 25,6 & 14 & 32,6 & 11 & 25,6 & 2 & 4,7 \\
\hline
\end{tabular}

Tablo 5'teki "Maddelere İlişkin Frekans ve Yüzde Dağılımları" tablosundaki sonuçlara göre Türkçe öğretmenleri tarafından; "Resimler öğrencilerin sosyal/duygusal gelişimine uygundur." 
maddesine $\% 67,4+\% 16,3$ "kesinlikle kat1lıyorum+katıllyorum" cevapları toplamda $\% 83,7$ değerini vermiştir. Oranın bu kadar yüksek çıkması ders kitapları hazırlanırken rehberlik uzmanlarından yardım alındığını göstermektedir.

"Resimler metni tahmin etme, kestirme ve yordama becerilerini geliştirme açısından yeterlidir." maddesine \%48.8 "katılıyorum" ve "Resimler öğrencilerin yaratıcı düşünme becerilerini geliştirmektedir." maddesine \%51.2 oranlarında verilen "katılıyorum" cevapları resimlerin öğrencinin düşünmesine ve beyin firtınası yapmasına olanak sağladığını göstermektedir.

"Metin ve resimlerin yerleştirilmesinde zemin-fon ilişkisine dikkat edilmiştir." maddesine \%39.5 "katılıyorum"; "Resimlerin sayfadaki konumlandırması uygundur." maddesine \%44.2 oranında "katılıyorum" cevaplarının verilmesi konumlandırma ve zemin-fon ilişkisine daha da dikkat edilmesi gerektiğini ortaya çıkarmıştır.

"Resimler öğrencilerin hayal gücünü geliştirmeye yöneliktir." maddesine $\% 44.2$ oranında "katıliyorum, \%18,6 "katılmıyorum" ve "\%25,6 oranında ise "kararsızım" cevapları verilmiştir. Bu oranlara bakıldığında öğretmenlerin bile resimlemeler konusunda net bir kanıya varamaması, kitaplardaki resimler konusunda ciddi bir problemin olduğunu ortaya koymaktadır. Tepecik ve Kayabekir'e (2017, s. 1649) göre doğru resimlemeler çocuğa anlamlı yapılar oluşturması için çocuğun görsel algısını ve bilişsel sistemiyle tam etkileşim içerisinde bulunarak hayal etme ve düşünmenin temelini oluşturmasını sağlar. Ayrıca Kara da (2012, s. 230) çocuk okunanın veya okuduğunun karşıllğını resimlerin yansıtmasını istediğini belirterek resmin düşündürme görevinin önemine değinmiştir. Ayrıca resimler metin ile çelişmemeli ve farklı tür anlamlandırmalara sebep olmamalıdır. Günümüzde metin ve resimlendirilmesi arasındaki denge değişmiş, resimlemenin artık metinden öte farklı bir anlatım diline sahip olduğu belirtilmiştir. Resimler metinde anlatılanları göstermenin ötesinde metnin ana düşüncesiyle örtüşen ve aynı zamanda da yeni ve zengin ayrıntıları da içerisinde barındıran konumdadır. Bu gelişme algılamayı zorlaştırmaya ve karmaşaya sebep olmayacak şekilde uygulandığında çocuğun yaratıcılık ve hayal gücüne faydalı olacağını belirtmiştir.

"Resimler metinde verilmek istenen iletileri desteklemektedir." maddesine \%65.1 "katıliyorum"; "Resimler metinde yer alan kavramlara gönderme yapmaktadır." maddesine \%60.5 "katılıyorum"; "Resimler öğrencide metni okumaya yönelik merak uyandırmaktadır." maddesine \%58.1 "katılıyorum", ve "Resimler metinlerin başlıklarını desteklemektedir." maddesine de \%55.8 oranlarında "katılıyorum" cevaplarının verilmesi resim-metin göndermesinin uyumlu olduğunu göstermektedir.

"Metin için resimlerin yanı sıra karikatür, fotoğraf, grafik vb. öğelere yer verilmiştir." maddesine $\% 69.8$ oranında katılıyorum cevabı verilmiştir. Bunun yanında "Resimler günlük hayatla ilişkilidir." maddesine \%32,6 gibi düşük bir oranda "katılıyorum" cevaplarının verilmesi resimlerin, kullanılan karikatür, fotoğraf vb. ögeleri kadar güncel olmadığını göstermektedir.

Çalışmaya katılan Türkçe öğretmenleri "Metinler için yeterli sayıda görsel kullanılmıştır. "maddesine \%34,9 oranında katılıyorum, \%30,2 oranında katılmıyorum; "Resimlerde mantık hataları yapılmamıştır." maddesine ise $\% 30,1$ oranında katılıyorum, $\% 30,1$ oranında katılmıyorum şeklinde görüş bildirilmiştir. Öğretmenlerin bu maddelere vermiş olduğu katılıyorum ve katılmıyorum cevapları birbirine yakın olduğundan net bir görüşe sahip olmadıkları söylenebilir.

Tablo 5'deki sonuçlara göre Türkçe öğretmenleri tarafindan "Resimlerde albeni oluşturan renkler kullanılmıştır." maddesine \%30,2, "Resimlerde mat ve soluk renkler kullanılmamıştır." maddesine $\% 32,6$ oranında kararsızım cevabı verilmiştir. Öğretmenlerin bu maddeler için de net bir görüşe sahip olmadıklarını söylenebilir. 
Tablo 6: Cinsiyet Değişkenine Göre 6. Sınıf Türkçe Öğretmenlerinin Resim -Metin İlişkisine Yönelik Görüşlerine Dair T Testi Sonuçları

\begin{tabular}{|c|c|c|c|c|c|c|}
\hline \multirow{3}{*}{ Cinsiyet } & Grup & F & $\bar{X}$ & ss. & $\mathrm{T}$ & $P$ \\
\hline & Erkek & 28 & 2,6482 & 0,65581 & \multirow[b]{2}{*}{,268 } & \multirow[b]{2}{*}{ 790 } \\
\hline & Kadın & 15 & 2,5967 & 0,47527 & & \\
\hline
\end{tabular}

Tablo 6'daki sonuçlara göre erkek ve kadınların aritmetik ortalaması birbirine yakındır. Bununla beraber $P$ değerinin 0.05 'den $(0,790>0,050)$ büyük olması, cinsiyet değişkeni ile $6 . \sin ı f$ Türkçe öğretmenlerinin görüşleri arasında anlamlı bir farklılık olmadığı saptanmıştır.

Tablo 7: Yaş Değişkenine Göre 6. Sınıf Türkçe Öğretmenlerinin Resim -Metin İlişkisine Yönelik Görüşlerine Ait Varyans Analiz Sonuçları

\begin{tabular}{|c|c|c|c|c|c|c|}
\hline & Grup & $\mathrm{N}$ & $\bar{X}$ & ss. & $\mathrm{F}$ & $\mathrm{P}$ \\
\hline \multirow[t]{5}{*}{ Yaş } & $18-24$ & 1 & 1,30 & - & \multirow{5}{*}{2,188} & \multirow{5}{*}{0,561} \\
\hline & $25-31$ & 30 & 2,7167 & 0,60790 & & \\
\hline & $32-38$ & 10 & 2,5350 & 0,46431 & & \\
\hline & $39-45$ & 2 & 2,4750 & 2,4750 & & \\
\hline & 46 ve üstü & - & - & - & & \\
\hline
\end{tabular}

Tablo 7'deki sonuçlara göre, 6.sınıf Türkçe öğretmenlerinin resim-metin ilişkisine yönelik görüşleri ile yaş değişkeni arasında anlamlı bir farklılık yoktur ( $\mathrm{p}<0,05$ fark anlamlı $=>0,561<0,05$ ).

Tablo 8: Hizmet Süresi Değişkenine Göre 6. Sınıf Türkçe Öğretmenlerinin Resim -Metin İlişkisine Yönelik Görüşlerine Ait Varyans Analiz Sonuçları

\begin{tabular}{|c|c|c|c|c|c|c|}
\hline \multirow{6}{*}{$\begin{array}{l}\text { Hizmet } \\
\text { Süresi }\end{array}$} & Grup & $\mathrm{N}$ & $\bar{X}$ & ss. & $\mathrm{F}$ & $\mathrm{P}$ \\
\hline & $1-3$ & 16 & 2,6656 & 0,82960 & \multirow{5}{*}{0,211} & \multirow{5}{*}{0,231} \\
\hline & $3-6$ & 16 & 2,6719 & 0,40496 & & \\
\hline & $7-10$ & 8 & 2,4750 & 0,48033 & & \\
\hline & $10-15$ & 2 & 2,7500 & 0,28284 & & \\
\hline & 15 ve üstü & 1 & 2,4000 & - & & \\
\hline
\end{tabular}

Tablo 8'deki sonuçlara göre, 6.sınıf Türkçe öğretmenlerinin resim-metin ilişkisine yönelik görüşleri ile hizmet süresi değişkeni arasında anlamlı bir farklılık yoktur $(\mathrm{p}<0,05$ fark anlamlı $=>$ $0,231<0,05)$.

Tablo 9: Öğrenim Durumu Değişkenine Göre 6. Sınıf Türkçe Öğretmenlerinin Resim Metin İlişkisine Yönelik Görüşlerine Ait Varyans Analiz Sonuçları

\begin{tabular}{lllllll} 
& Grup & $\mathrm{N}$ & $\overline{\mathrm{X}}$ & ss. & $\mathrm{F}$ & $\mathrm{P}$ \\
\cline { 2 - 6 } \multirow{3}{*}{ Öğrenim } & Fakülte & 42 & 2,6250 & 0,59982 & \multirow{2}{*}{0,137} & \multirow{2}{*}{0,713} \\
\cline { 2 - 5 } & Yüksek Lisans & 1 & 2,8500 & - & & \\
\cline { 2 - 6 } & Doktora & - & - & - & & \\
\hline
\end{tabular}

Tablo 9'daki sonuçlara göre, 6.sınıf Türkçe öğretmenlerinin resim-metin ilişkisine yönelik görüşleri ile yaş değişkeni arasında anlamlı bir farklılık yoktur ( $\mathrm{p}<0,05$ fark anlamlı $=>0,713<0,05$ ). Öğrenim durumu değişkenine göre doktora seviyesinde bir katılım gerçekleşmemiştir. Doktora seviyesinde eğitimin verilmesi, öğretmen yeterliliği konusunda önemlidir. Ingersoll (2012, s. 47) mesleğe yeni başlayan öğretmenler adeta denize atılmakta ve bu öğretmenlere "ya yüz ya da boğul" denilmektedir diyerek mezuniyetten sonra da öğretmenlerin eğitimlerine devam ettirilmesi gerektiğini belirtmiştir. 


\section{Sonuç ve Tartışma}

6. sınıf Türkçe ders kitaplarının resim-metin ilişkisine yönelik Türkçe öğretmenlerinin görüşlerine dayanılarak elde edilen verilerden şu sonuçlara ulaşılmıştır:

Türkçe ögretmenleri, "Resimler günlük hayatla ilişkilidir." maddesine \%32,6 oranında "katılıyorum", \%27,9 oranında "kararsızım ve katılmıyorum" cevaplarını vermiştir. Bu oranlamalardan hareketle resimlerin günlük hayatla ilişkilendirilmesi konusunda, Türkçe öğretmenleri arasında ciddi bir görüş farklılıkları vardır. Bulunan bu sonuçla ilgili, Nespeca \& Reeve (2003, s.2) resimli kitapları, çocuğun günlük yaşamındaki deneyimlerini içeren metinlerden oluştuğunda çocuğa fikir ve hayal kazandıran önemli birer sanat eseri olarak tanımlamaktadır. Uzuner, Aktaş ve Albayrak (2010) tarafindan yapılan çalışmada katılımcılar, Türkçe 6, 7, 8. sınıf ders kitaplarındaki görsellerin öğrencilerin yaratıcı düşünme becerilerini geliştirme ve onlara estetik zevk kazandırma noktasında eksiklikleri olduğunu ifade etmişlerdir. Ceyhan ve Yiğit (2005, s.102) ise ders kitab1 resimlemek, bir vitrin veya sergiyi düzenlemeye benzer ve iyi düzenlenen bir ders kitabı beraberinde başarıyı getireceğini belirtmiştir. Ayrıca Kırbaş, Orhan, Topal (2012) tarafindan 8. sınıf Türkçe ders kitaplarındaki görsel öğelerin değerlendirildiği çalışmada da araştırmaya katılan öğretmenler, görsellerin öğrencilerin yaratıcı düşünme becerilerini geliştirmede yetersiz olduğu görüşündedirler. Ayrıca "kararsızım" cevabının da yüksek olması, resimler ile günlük hayat ilişkisine dikkat edilmediği sonucunu da ortaya çıkarmıştır.

Renkler, özellikle ilköğretim öğrencileri için önemlidir. Renkler; beyin gelişimine, yaratıcılığa, verimliliğe ve öğrenmeye faydalı önemli bir unsurdur. Resimlerde kullanılan albeni (çekici) oluşturan renkler öğrencilerin dikkatini resme vermesinde önem arz etmektedir. "Resimlerde albeni oluşturan renkler kullanılmıştır." ve "Resimlerde mat ve soluk renkler kullanılmıştır." maddelerine verilen cevaplar dikkate alındığında öğretmenler yüksek oranda "kararsızım" demiştir. $\mathrm{Bu}$ sonuçtan hareketle öğretmenlerin resimlerdeki renklere dikkat etmediği, önem vermedikleri ve yetersiz oldukları sonucu çıkarılabilir. Atmaca (2006, s. 318-328) ders kitaplarında yer alan renklerin çok önemli olduğunu, resimlerde ana ve canlı renklerden yararlanılması, bulanık renklerden kaçınılması gerektiğini belirtmiştir. Karatay ve Pektaş'a (2012) göre renk seçiminde çocukların gelişim dönemlerine dikkat edilmeli daha çok yakınlık ve sıcaklık etkisi yaratan sıcak renkler kullanılmalıdır. Ayrıca özellikle kullanılan renklerin doğadaki renklerle uyumlu olması önem taşımaktadır. Psikologlara göre sarı ve kırmızı renkler sıcak renklerdir, mutluluk ve heyecan içerir, mavi ve yeşil renkler ise sakinlik içermektedir (Mercan, 2015, s.22). Renk konusunda Çalık'ın (2001, s.10) insanların sarı renge bakma eğilimlerinin olduklarını belirtmesi ve ders kitaplarında ön plana çıkarılmak istenen yerlerin sarı renk kullanılarak yazılması gerektiğini söylemesi de renk-resimmetin uyumunun ne kadar önemli olduğunu vurgulamaktadır.

"Metinler için yeterli sayıda görsel kullanılmıştır." maddesine verilen "katılıyorum ve katılmıyorum" düzeyindeki yanıtlar birbirine çok yakındır. Buradan hareketle ders kitabındaki görsellerin metinler için yetersiz olduğu ve görsel tasarımcıların, görsel zenginliği artırmaları gerektiği sonucu çıkarılabilir.

Türkçe öğretmenleri resimlerin; öğrencilerin sosyal/duygusal gelişime uygun, yaratıcı düşünmesini ve hayal gücünü geliştiren, öğrencide sanatsal beğeni oluşturan önemli bir unsur olduğu ortak görüşler çerçevesinde söylenebilir. "Resimlemeler; konuların, kavramların, duyguların ve sosyal becerilerin öğretilmesinde ve görsel algılama yetilerinin gelişmesinde etkili olmakta ve hızlı ve kalıcı öğrenmeyi sağlamaktadır" (Sazak vd., 2018, s. 2227-2242). Çıkan sonuçlara göre resimlerin merak uyandırdığı ve öğrenciler tarafindan metinlerin ilgi çekici bulunduğu görülmüştür. Bu sonuç Yıldız vd.'nin (2016, s. 43-55) resimlemeler hem metinde işlenen konu, olay ve ana fikri kavramaya yardımcı olur hem de eseri öğrenciler tarafından çekici kılar söylemiyle uyuşmaktadır. Ayrıca çocuk-resim ilişkisiyle alakalı yapılan çalışmalarda kendini ifade edemeyen çocukların resimlemelerle kendini ifade ettiği görülmektedir (Artut 2004; Matthews 2003; Skybo, 
RyanWengwe ve Su 2007; Yavuzer 2007; Yolcu 2004). Bu şekilde kendini resimle ifade etmeyi tercih eden çocukların ders kitaplarında karşılaşacağı resimlerin de bahsedilen kalitede olması gerekmektedir.

"Resimler metinde verilmek istenen iletileri desteklemektedir." maddesine \%65.1 "katılıyorum"; "Resimler metinde yer alan kavramlara gönderme yapmaktadır." maddesine \%60.5 "katılıyorum"; "Resimler öğrencide metni okumaya yönelik merak uyandırmaktadır." maddesine \%58.1 "katılıyorum", ve "Resimler metinlerin başlıklarını desteklemektedir." maddesine de \%55.8 oranlarında "katılıyorum" cevaplarının verilmesi resim-metin göndermesinin uyumlu olduğunu göstermektedir. Ercantürk’e (2015, s.427-454) göre metin ve görsel uyumu Türkçe dersinin hedeflere ulaşmasında çocukların hazırbulunuşluklarını artırmakta ve kişiliklerinin gelişimine katkı sağlamaktadır.

Resimlerin öğrencilerde tahmin etme, kestirme ve yordama becerilerini geliştirdiği, metinfon ilişkisine dikkat edildiği, resimlerin metindeki hikâye unsurları ile örtüştüğü, resimlerin metinde verilen iletileri desteklediği bulgulardan elde edilmiştir. Karadağ (2019, s. 127) metinlere ait resimler, metinle ilişkili olduklarında öğrencilerin metni tahmin etmesi kolaylaşacak ve anlamlı öğrenme sağlanmış olacaktır diyerek bulgularla örtüşen bir açıklama yapmıştır. Okunabilirlik açısından metinfon ilişkisi önemle ele alınmalıdır (Sürmeli ve Kaptan, 2011, s.577-584).

Araştırmadan çıkan diğer sonuçlar ise; resimlerin merak uyandırdığı; sayfada uygun konumlandırıldığı, metinlerin başlıkları desteklediği, metinde yer alan kavramlara gönderme yapıldığı, resim-metin ilişkisinin yapılandırmacı yaklaşıma uygun olduğu, metin ve resmin birbiriyle uyumlu olarak hareket ettiği, resimlerin dışında farklı görsel ögelere yer verildiği yönündedir. Ulaşılan sonuçları destekleyen Kılıç ve Seven'e (2007) göre ders kitaplarında resimler ve fotoğraf dışında karikatürlere, grafiklere, şemalara, tablolara ve haritalar gibi görsellere anlatımı zenginleştirmesi açısından yer verilmelidir. Kitaplarda yer alan anlatımı güç olan konuların daha kolay anlaşılmasını sağlayan, açıklığa kavuşturan grafikler basit çizilmiş olmalı ve sadece bir düşünceyi yansıtmalıdır (Ceyhan ve Yiğit, 2005).

Türkçe ögretmenlerinin 25-31 yaş aralığında ve 1-3 ve 3-6 yıl aralığında yoğunlaştığı görülmektedir. Bu durum hem öğrenci açısından yaş aralığı bakımından avantajlı, hizmet süresi ve tecrübe açısından ise dezavantajlı bir durum oluşturmaktadır. Türkçe öğretmenlerinin metin-resim ilişkisine yönelik görüşleri dikkate alınacak olursa Türkçe öğretmenlerinin görüşlerinin; cinsiyet, yaş, öğrenim durumu ve hizmet süresi değişkenlerine bağlı olarak anlamlı bir farklılık göstermediği tespit edilmiştir.

\section{Öneriler}

“Ortaokul 6.Sınıf Türkçe Ders Kitaplarındaki Metin-Resim İlişkisinin Metni Anlamlandırmaya Etkisinin İncelenmesi” adlı çalışmadan elde edilen verilerden hareketle şu önerilerde bulunulabilir:

$\checkmark$ Ders kitaplarında ele alınacak resimler yeterli düzeyde günlük hayatla ilişkili olmalıdır.

$\checkmark$ Resimler, metni anlamlandırma hususunda çok önemli bir yere sahiptir. Bundan dolayı resimlerde mantık hatalarının olması, metni anlamlandırmayı olumsuz etkilemektedir. Görsel tasarımcılar tarafindan hazırlanan resimler, mantıksal bütünlük içinde olmalı ve buna dikkat edilmelidir.

$\checkmark$ Öğrenciler için önemli bir uyarıcı olan renkler, öğrencilerin bilişsel ve duyuşsal düzeylerine uygun olarak ders kitaplarında yer verilmelidir. Öğretmenler tarafından da resimlerdeki renkler dikkate alınmalıdır.

$\checkmark$ Metinler görsel ögelerle zenginleştirilmelidir. 
Özellikle öyküleyici metinlerde tahmin etmeyi kolaylaştıracak resimlemeler seçilmelidir. Yine öyküleyici metinlerde öğrenciye verilmek istenen mesajın sezdirilmesinde de resimlemeler önemli bir rol oynamaktadır.

\section{Kaynakça}

Arı, S. (2008). MEB, ilköğretim yedinci sınıf Türkçe ders kitabında resimlerin içerikle uyumu. Yayımlanmamış yüksek lisans tezi. Abant İzzet Baysal Üniversitesi Sosyal Bilimler Enstitüsü, Bolu. https://doi.org/10.11616/basbed.vi.455270

Artut, K. (2004). Okul öncesi resim eğitiminde çocukların çizgisel gelişim düzeylerine ilişkin bir inceleme. Çukurova Üniversitesi Sosyal Bilimler Enstitüsü Dergisi. 223. 13 (1). https://doi.org/10.18506/anemon.523567

Atmaca, A. (2006). İlköğretim ders kitaplarında görsel tasarım ve resimleme. Milli Ĕgitim Dergisi, (171), 318-328.

Baş, B. Yıldız F.İ. (2014). İlkokul Türkçe ders kitaplarının resim-metin ilişkisi açısından öğretmen görüşlerine göre değerlendirilmesi. Mustafa Kemal Üniversitesi Sosyal Bilimler Enstitüsü Dergisi, 28, 139-151. https://doi.org/10.17218/hititsosbil.289419

Becer, E. (1996). Bir kitabın grafik tasarımı: armonik kurallar, değerlendirme yöntemleri ve değişen koşullar. Türkiye ve Almanya'da İlköğretim Ders Kitapları. Ankara: Türk-Alman Kültür İşleri Kurulu Yayın Dizisi No:11.

Carney, R. Levin, J.R. (2002). Pictoral 1llustrations still improve students learning from text. Educational Psychology Review. Vol. 14, No. 1. https://doi.org/10.1023/A:1013176309260

Ceyhan, E. ve Yiğit, B. (2005). Konu alanı ders kitabı incelemesi. Ankara: Anı Yayıncılık.

Christensen, B. L., Johnson Burke, R. \& Turner, A. L. (2015). Research methods design and analysis (araştırma yöntemleri desen ve analiz). (çev. ed. Ahmet AYPAY). 2. Baskı. Ankara: Anı Yayıncilik.

Creswell, J. W. (2013). Araştırma deseni. (çev. ed. Selçuk Beşir Demir). İstanbul: Eğiten Kitap.

Çalık, T. (2001). Türkçe ders kitaplarının biçim ve tasarımı. L. Küçükahmet (Editör). Konu alanı ders kitabı inceleme kllavuzu Türkçe (1-16). Ankara: Nobel Yayın Dağıtım. https://doi.org/10.14527/9786053640738.09

Demirel, Ö. Kıroğlu, K. (2005). Konu alanı ders kitabı inceleme. PegemA Yayıncılık, Ankara.

Ercantürk, O. K. (2015). Türkçe ders kitaplarındaki yazılı metinler ile metin görsellerinin uyumu. Turkish Studies, 10(3), 427-454. https://doi.org/10.7827/turkishstudies.7826

Gönen, M. Katrancı, M. Uygun, M. ve Uçuş, Ş. (2011). İlköğretim birinci kademe öğrencilerine yönelik çocuk kitaplarının, içerik, resimleme ve fiziksel özellikleri açısından incelenmesi. Ĕ̈itim ve Bilim Dergisi, 36 (160), 250-265. https://doi.org/10.16986/huje.2015014224

Ingersoll, R.M. and Merrill, E. (2011). The status of teaching as a profession. In J. Ballantine and J. Spade (Eds.), Schools and Society: A Sociological Approach to Education. (pp.185-189). 4th Ed. CA: Pine Forge Press.

İşcan, A. Cımbız A. T. (2018). Ortaokul 5. sınıf Türkçe ders kitabındaki resimlerin metinlerle uyum düzeyinin incelenmesi. Abant İzzet Baysal Üniversitesi Ĕ̈itim Fakültesi Dergisi, 18 (1), 252. https://doi.org/10.17240/aibuefd.2018..-380009 
Kara, C. (2012). Çocuk kitabı seçiminde resimlemelerle ilgili olarak ebeveynin dikkat etmesi gereken başlica unsurlar. Batman Üniversitesi Yaşam Bilimleri Dergisi, 1 (1), 225-232.

Karadağ, K. (2019). Illkokul 4. Sinıf Türkçe Ders Kitabındaki Resimlerin Metinlerle Uyumunun Incelenmesi. Yayımlanmamış yüksek lisans tezi. Tokat Gaziosmanpaşa Üniversitesi Eğitim Bilimleri Enstitüsi, Tokat.

Karasar, N. (1999). Bilimsel araştırma yöntemi: kavramlar, ilkeler, teknikler. Nobel Yayınları, Ankara.

Karatay, H. ve Pektaş, S. (2012). Türkçe ders kitaplarının incelenmesine yönelik ölçek geliştirme çalışması. Adlyaman Üniversitesi Sosyal Bilimler Enstitüsü Dergisi, 10, 183-204. https://doi.org/10.14520/adyusbd.315

Kayabekir, T. Tepecik, A. (2017). Resim-metin ilişkisinde yapısal ve bilişsel kavramların tasarım sürecine etkisi. Atatürk Üniversitesi Sosyal Bilimler Enstitüsü Dergisi 21(4):1641-1653.

Kılıç, A. (2006). İlköğretim ders kitaplarındaki resimlemelerin çocuğun görsel sanat eğitimine katk1ları. Ondokuz Mayıs Üniversitesi Ĕ̆itim Fakültesi Dergisi, 21, 24-29.

Kılıç, A. ve Seven, S. (2007). Konu Alanı Ders Kitabı İncelemesi. Ankara: Pegem A Yayıncılık.

Kırbaş, A. Orhan, S. ve Topal, Y. (2012). İlköğretim türkçe ders kitaplarındaki görsel öğelere öğretmen görüşlerinden hareketle eleştirel bir bakış. Turkish Studies, 7(4), 2225-2235.

Küçükahmet, L. (2001). Konu alanı ders kitabı inceleme. Nobel Yayın Dağıtım, Ankara.

Mardi, H. Ö. (2006). Çocuk Kitapları Resimlemede Karakter Yaratma. Yayımlanmamış yüksek lisans tezi, Dokuz Eylül Üniversitesi, İzmir.

Matthews, J. (2003). Drawing and painting: children and visual representation (Second Edition). London: Paul Chapman Publishing.

Mercan, Z. (2015). Okul öncesi dönem çocuk kitaplarında resimlemenin ögrretmen görüslerine göre incelenmesi. Yayımlanmamıs yüksek lisans tezi. Abant İzzet Baysal Üniversitesi, Bolu. https://doi.org/10.17240/aibuefd.2017.17.28551-304638

Millî Eğitim Bakanlığı ders kitapları ve eğitim araçları yönetmeliği (2012). Resmi Gazete (12.09.2012). Say1: 28409.

Nespeca, S. M. \& Reeve, J. B. (2003). Picture Books Plus. USA: American Library.

Oğuzkan, A. F. (2001). Çocuk edebiyatı. Ankara: Anı Yayıncılık.

Sazak, E , Per, M , Türker, O . (2018). Kaynaştırma sınıfı öğretmenlerinin ilkokul ders kitaplarında ve derslerde illüstrasyon kullanımına ilişkin görüşleri. Abant İzzet Baysal Üniversitesi $\begin{array}{lllll}\text { Eğitim } & \text { Fakültesi } & \text { Dergisi, } & 18 & \text { (4), }\end{array}$ https://doi.org/10.17240/aibuefd.2018.18.36740-473472

Sürmeli, K. ve Kaptan, A. Y. (2011). Çocuk dergilerinin grafik tasarımı. 3. Ulusal Çocuk ve Gençlik Edebiyatı Sempozyumu (5-7 Ekim 2011) Bildirileri, Ankara: Ankara Üniversitesi Basımevi, s. $577-584$.

Skybo, T. Ryan-Wengwe, N. \& Su, Y. (2007). Human figure drawings as a measure of children's emotional status: critical review for practice. Journal of Pediatric Nursing, Vol 22, No 1 (February). https://doi.org/10.1016/j.pedn.2006.05.006

Soydan, K. (2014). Türk kültürüne göre çocuk hikâye kitaplarında illüstrasyon. Yayımlanmamış yüksek lisans tezi. İstanbul Arel Üniversitesi, İstanbul. 
Şahin, T. Y.Yıldırım, S. (1999). Öğretim teknolojileri ve materyal geliştirme. Anı Yayıncılık, Ankara.

Yavuzer, H. (2007). Resimleriyle çocuk. İstanbul: Remzi Kitabevi.

Yolcu, E. (2004). Sanat eğitimi kuramlarl ve yöntemleri. Ankara: Nobel Yayıncılık. https://doi.org/10.14527/9786052414835

Uzuner, S. Aktaş, E. ve Albayrak, L. (2010). Türkçe 6, 7 ve 8. Sınıf Ders Kitaplarının Görseller (İllüstrasyonlar) Açısından Değerlendirilmesi. Türklük Bilimi Araştırmaları, 27, 721-733. 